\title{
THE SKIRMISH AT GATBERG: A PERSPECTIVE ON THE UTILISATION OF BLACK AUXILIARIES DURING THE SOUTH AFRICAN WAR ON THE TRANSKEI BORDER (1899-1902)
}

Pieter Labuschagne
Department of Political Sciences, UNISA

\begin{abstract}
The South African War (1899-1902) created major rifts in the post-war society as a result of various controversies that emanated from the conflict, which left a long legacy of bitterness and in many ways inhibited nation-building in the country. One contentious issue that had a major influence on society during and after the War was that of the role and participation of black auxiliaries who were deployed against the Boer forces. After the hostilities had ended, many publications dealt with the topic at both a general and an individual level. The aim of the study on which this article reports, was to analyse the topic at an individual level, specifically focusing on an incident that occurred at Gatberg on 20 November 1901. The skirmish near the former Transkei border occurred between a Boer commando and a black unit under the command of a British officer, and resulted in a great deal of bitterness and controversy that lasted for many years after the conclusion of the War. In the article, the clash is described and placed in its historical context in order to explain what transpired on that fateful day. The article explains the animosity that was generated by the incident, but also the contrasting views that existed after the incident.
\end{abstract}

\section{Introduction}

The deconstruction in historiography of broader events within a postmodernistic context significantly highlights lesser-known incidents and role players

Scientia Militaria, South African Journal of Military Studies, Vol $41, \mathrm{Nr} 2,2013$, pp. 78-91. doi : $10.5787 / 41-2-1069$ within the broader ambit. The shifting and the sharpening of the focus onto lesser-known incidents and role players provide new perspectives or reinforce current perspectives and insights of events. The deconstructed 
approach also allows a more strongly nuanced and detailed picture of events, which could in turn explain broader developments and general trends in history.

The multifaceted history of the South African War (1899-1902) still intrigues researchers and continues to stimulate research, which often results in important shifts of emphasis and in direction shifts in historiography. In some instances, the shifts in focus can result in important broader paradigm shifts within the discipline. One important paradigm shift within the context of the South African War on the participation of black people occurred in 1983 when Peter Warwick published his work, Black People and the South Africa War. ${ }^{1}$

Warwick's publication, and other subsequent publications that probed the same theme, reinforced the paradigm shift and highlighted the role of black people in the War. The Warwick publication and subsequent research managed to perforate the myth of a 'white man's war'.

A subtheme to the broader theme of the participation of black people in the South African War (which had been perceived as a white man's war), was the highly controversial practice of deploying black people against the Boer forces. Warwick and Bill Nasson, within the broader ambit of their publications, provide valuable insights into the adverse perceptions harboured by whites (in the then Cape Colony and Boer Republics) of the deployment of black troops or auxiliaries against Boer forces. This negative perception was fuelled by the then prevalent perception of the South African War being a 'white man's war'. ${ }^{2}$

Within their exposition of the theme of black participation and the reaction of the Boer Republics to the War, both Warwick and Nasson briefly refer to a very significant but largely obscured skirmish or clash that occurred at Gatberg, close to the Transkei border, on 21 November 1901. ${ }^{3}$ Although the magnitude of the skirmish at Gatberg is not comparable to that of any of the better-known and larger battles fought during the War, its significance should not be negated or overlooked. The clash at Gatberg near Ugie served as a strong demonstration of the adverse feelings that were harboured by the Boer leaders and burghers against the deployment of black soldiers or levies against them, and the political implications thereof.

The purpose of this article is to describe the skirmish at Gatberg in November 1901 in order to demonstrate these strong adverse feelings and reactions amongst the Boers. However, the aim is to look at it from an individual perspective, specifically from that of Commandant JAJ Bezuidenhout, on the fateful day. The 
negativity harboured against the black forces was inter alia due to what was perceived as the brutality displayed by black soldiers in a 'gentlemen's war'. What transpired at Gatberg was seen as a demonstration and validation of this perspective and diverse perceptions that were harboured by many of the white population about black participation in the War.

For many decades after the War had ended, the participation of black people in the South Africa War was ignored. However, the void has been significantly addressed by Warwick's ground-breaking publication on the role of black people in the War. This publication inspired a number of subsequent publications that shifted the attention to the participation of blacks in the War.

Nasson had a strong regional emphasis and a specific focus on the impact of the War on black and coloured men who were inadvertently sucked into the conflict, and the tragedy it brought to their lives.

An underlying theme that emanated from this and subsequent research on black participation was that of the adverse feelings on both sides, but particular on the side of the Boers and their supporters. As Nosipho states, there was "an unwritten agreement between the leaders on both sides that blacks should not be armed for the struggle". 4 This belief was very strongly held in the white community.

The controversy about the participation of black people during the War led to many accusations and counter-accusations. One noteworthy response early in the War came from General Piet Cronjé, who wrote to Colonel Baden-Powell during the siege of Mafeking and strongly expressed his feelings in this regard. In his letter, Cronjé stated that he understood that Baden-Powell was arming Bastards, Fingos and Baralongs against the Boers. He warned Baden-Powell that they "have committed an enormous act, the wickedness of which is certain, and the end of which no man can foresee". 5

\section{The clash at Gatberg}

The clash at Gatberg must be seen within the broader framework of the formation of various units of black soldiers in the Transkei and elsewhere in the region, under the command of white British officers, to ensure the security of the areas. The main task of the newly formed units was to repel Boer commandos that penetrated deep into the Eastern Cape, close to the Transkei border, in order to escape the dragnet of British forces in the Northern Cape. 
In the literature on the South African War, the clash at Gatberg, close to Ugie in the North-Eastern Cape, was reduced to a short paragraph or a few sentences in a few sources. The authoritative Times History of the South African War ${ }^{6}$, for example, did not include a reference to the clash in their extensive work on the South African War. Nasson refers as follows to the clash at Gatberg:

But the only noteworthy incident in the Transkeian region was an altercation in November 1901, when a small detachment of Boers under Commandant Bezuidenhout penetrated the Maclear district in East Griqualand and clashed with a large African force. The weaker Republican force was routed. ${ }^{7}$

Warwick also included a reference to the clash in his work:

... the only significant confrontation that took place with the levies in the neighbourhood of East Griqualand. On 19 November Bezuidenhout with fifty-three men invaded Maclear district and moved towards Gatberg, where, on the next day, he was met by Captain Herbert Elliot, the son of the Chief Magistrate, with 300 black levies. A brief engagement followed, in which Elliot was killed, before the Boer force withdrew with the loss of six men. ${ }^{8}$

The clash or skirmish that Nasson and Warwick refer to lasted for only a few minutes. As mentioned above, it took place on 20 November 1901, and occurred near Gatberg (Ugie) in the North-Eastern Cape. Not only was the clash of short duration, but only few deaths resulted from it. It is therefore hardly surprising that the incident received very little attention apart from the two references already made.

However, the skirmish gave rise to a great deal of bitterness amongst those who were involved in it. This animosity reverberated not only at a personal level, but also fed into the broader divisions in the post-war society.

\section{A perspective on black participation during the South African War}

The deployment of black auxiliaries or levies under the command of British officers generally provoked strong feelings from the Boer leaders and from ordinary burghers in the commandos. One of many examples of such feelings was those of Ds (Revd) RDM McDonald, a parson in the field with one of the commandos. $\mathrm{He}$ stated in his bibliography on the War that, if a black spy was caught, no mercy was 
shown. ${ }^{9}$ In defence of such a policy, McDonald stated that it was construed as barbaric that black men were deployed in this capacity, and that blacks should have realised that the War had not been declared against them. He stated that drastic action was necessary to illustrate to black people that they were not participants in the War and therefore not entitled to the rights afforded to the Boer and British forces. $^{10}$

SB Spies, in his work on the South African War, Methods of Barbarism, also refers to the strong feelings amongst the Boer forces against the deployment of armed blacks during the War: "Boers in the field capturing armed blacks in the service of the British often shot them without compunction."11

The movement by Boer commandos into the eastern regions of the Cape Colony and the continuing vulnerability of the security situation in the area was a real concern for the British. This resulted in pressure on magistrates in the NorthEastern part of the colony to beef up their defences. The British forces repeatedly emphasised the necessity to arm small groups of coloured and black people to stem the invasion by Boers. The Cape Prime Minister, WP Schreiner, who was opposed to the strategy because of his ties with the Afrikanerbond, was one of the strongest opponents of this strategy. He felt that the British forces in the areas were sufficient to deal with the perceived threat of invasion by Boer commandos.

When General Hendrik Olivier occupied small towns such as Barkly East in the area, however, it was regarded as justification for the move to arm black people to defend these areas. This prompted General Buller to act. He ordered that black forces should be armed, which had a significant impact on later events. To prevent an escalation of hostilities, a deputation of Dutch farmers of the Elliot district set up a meeting with Olivier.

With the approval of Major Sir Henry Elliot, who commanded all forces in the Native Territories, Olivier was informed that if he and his forces crossed the line of the Drakensberg Native troops would be used in defence of the territories. ${ }^{12}$

Olivier's response was that Boer commandos had no intention of crossing the Drakensberg line and would remain on the border between the division of Barkly East and the districts of Elliot and Maclear. The black forces that were mobilised remained south of the line, and when Olivier withdrew over the Orange River, many of their units were disbanded. ${ }^{13}$ 
When Commandant Fouché moved into the area in July 1901 to raid for horses in the district of Maclear, ${ }^{14}$ however, it again prompted the mobilisation of black levies under the command of British officers. ${ }^{15}$ As a result, two forces were formed in the area, namely the Griqualand Field and Mount Fletcher Force under the command of Sir Walter Stanford, and the Tembuland Field Force under Captain Elliot. ${ }^{16}$ Elliot was deeply impressed by the scouting abilities and intelligence of the black auxiliaries and specifically that of chief Dalindyebo, whom he described as having secret agents there and anywhere. ${ }^{17}$

The deployment of coloured and black groups as scouts and armed troops increasingly became a source of friction and dispute between the British and the Boers in the Cape. Coloured and black spies were increasingly treated harshly by Boer commandos. In July 1901, Kritzinger informed Kitchener that any blacks deployed by the British army would be executed if they fell into Boer hands. ${ }^{18}$

\section{The clash at Gatberg 20 November 1901}

The prelude to the clash at Gatberg was the result of several drives organised by the British Military High Command in the North-Eastern Colony to create a pincer movement against the Boer commandos that operated deep in the region. Their actions forced the Boer commandos in the area deeper into the eastern part of the region. In Tembuland, mostly black units attempted to prevent Boer commandos from entering their areas.

Commandant (later General) Willem Fouché, who was active in the NorthEastern Cape, reacted to the drives and followed the well-known escape strategy of fragmenting his commando into two smaller units of soldiers. He placed his two field cornets, Jan Bezuidenhout and Ben Myburg, in command of the two smaller forces, which both moved closer to the Transkei. Bezuidenhout advanced with his section of men down the Barkly Pass into the eastern region between Maclear and Ugie. ${ }^{19}$ His small commando consisted of 53 men, predominantly burghers from the Rouxville area, and included men such as Captain Basil Potgieter, his brother, Field Cornet Wynand Bezuidenhout, and his father, Pieter Hendrik Schalk Bezuidenhout. $^{20}$

Bezuidenhout's unit hugged the lower slopes of Gatberg and moved cautiously towards Ugie. Black sentinels who were posted outside the town picked up on the invasion into the area and hurriedly reported the news back to Captain Elliot late on the afternoon of 19 November. Elliot commanded a unit that consisted of black soldiers and was stationed at Philips Kop near Ugie. ${ }^{21}$ 
Elliot moved out from Ugie before daybreak on 20 November along the lower slopes of Gatberg in the direction of Maclear. The strength of his force remains a matter of speculation, since estimates of the unit's numbers differ greatly. In his submission after the War in 1902 to the Attorney General, Bezuidenhout stated that Elliot's force during the clash consisted of 8000 black men. ${ }^{22}$ (The reported figure varies between the 8000 suggested by Bezuidenhout in his submission to the Attorney General after the War, ${ }^{23}$ the number 300 that appeared in the Northern Post of 23 November 1901, and the same number quoted in two official reports by Lieutenant Taylor and Major Raw, which were also submitted to the Attorney General.)

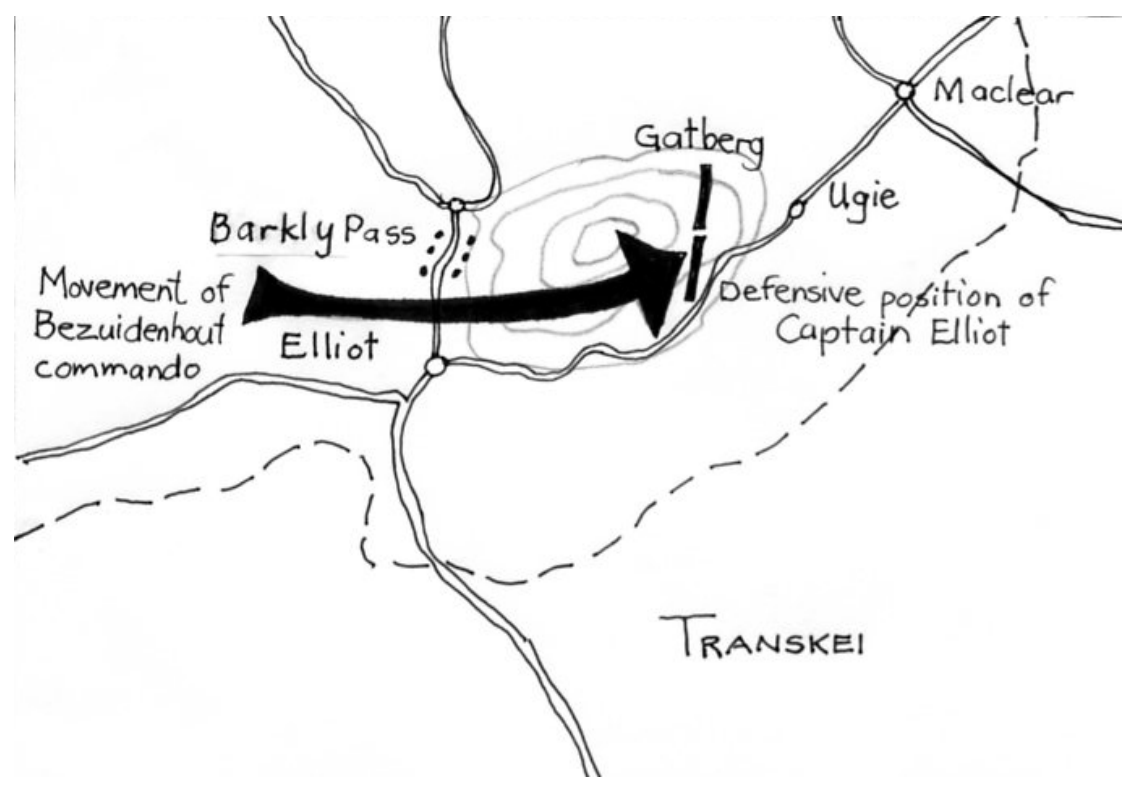

Figure 1: The position of the forces early on the morning of 20 November 1901

Early on the morning of 20 November, Bezuidenhout's unit moved along the lower slopes of Gatberg through the O'Dairn farm near Ugie and was soon thereafter engaged by Elliot and his black auxiliaries, who were positioned at Gatberg Nek. ${ }^{24}$ Elliot, who had been alerted by his black spies, had deployed his force in a defensive position early the morning and surprised the small Boer unit. The force under Elliot consisted of black soldiers and was armed with Martini Henry and Snider rifles. 
Major Raw, who commanded a force of black soldiers from Maclear, was close by and was blocking Thompson's Pass and Jordaan's Pass to prevent Bezuidenhout from crossing into the area. ${ }^{25}$

Elliot's unit engaged Bezuidenhout and his men at about 07h00 with a sharp barrage of rifle fire which caught them unawares. ${ }^{26}$ After a short but intense skirmish, Bezuidenhout and his burghers had to withdraw, but not without significant loss of life. The withdrawal was disorderly and the commando was driven up the mountain, and in the process was forced to abandon 40 of their horses and pack animals. ${ }^{27}$ The following four burghers lost their lives after the brief encounter: PA Labuschagne (19 years), TJ Botha (19 years), JF Jonker (17 years) and PJA Botha (15 years).

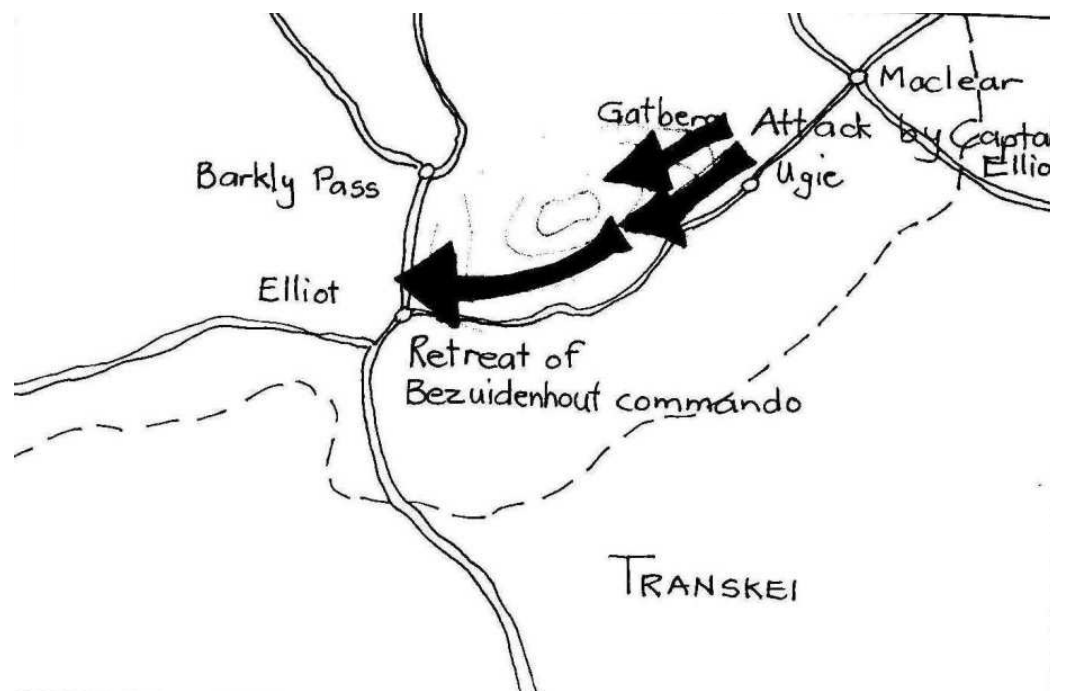

Figure 2: The position of the forces after the skirmish

On the side of the defenders, their commander Captain Elliot, son of the magistrate, was killed, as well as six of the black soldiers. Captain Elliot's father was Major Sir Henry George Elliot, Chief Magistrate of Tembuland, a former Crimean officer. $^{28}$

Pieter Hendrik Schalk Bezuidenhout, father of Field Cornet Bezuidenhout, who was wounded in the battle, surrendered under the white flag after the burghers 
had been forced to withdraw. ${ }^{29}$ (The commando, forced to retreat, was in the dark about what had happened to their wounded.) Bezuidenhout was in fact forced to walk to Ugie, where he died later that evening as a result of the wounds he sustained during the skirmish. A few black spies, who were despatched after the skirmish to establish the commando's position, were caught by the burghers and killed. ${ }^{30}$ After Bezuidenhout and his men had spent some time in a fruitless attempt to find out what had happened to the wounded, they had to withdraw in the direction of Aliwal North.

According to the reports (listed in the footnotes) by Lieutenant Taylor and Major Raw, submitted in reaction to Commandant Bezuidenhout's deposition to the Attorney General on 27 October 1902, two burghers (in addition to the wounded Bezuidenhout) were captured by black troops. One burgher was Allandale, a Cape Rebel from Elliot, and a 14-year-old boy, Van Jaarsveld. ${ }^{31}$ It has been suggested that Bezuidenhout most probably heard from the local farmer later that day that his father had died of his wounds at Ugie. ${ }^{32}$

\section{Aftermath of the clash of Gatberg}

The incident at Gatberg and the strength of the black forces in the area thwarted any further attempts by the Boers to invade the area beyond the Drakensberg line. Bezuidenhout moved further north and in early 1902, joined up with Odendaal's group, probably again under the command of Commandant Fouché. During the last months of the War, the commando moved closer to Aliwal North. During that period, Fouché was promoted to general and his two field cornets to the rank of commandant. However, a difference of opinion between the two new commandants and Fouché came to the surface, and the latter began to distance himself from the rest of the commando. ${ }^{33}$

Bezuidenhout refused to surrender to the British forces and remained in the field in the Northern Cape close to Aliwal North. He received an official report from Captain Clockwell, the CSO at Aliwal North, dated 3 June 1902. In the report, Bezuidenhout was instructed to remain in the area in anticipation of a visit by General Smuts, who requested to see him. ${ }^{34}$ This was followed by a directive from General Fouché, written by his secretary, L Botha, to all the burghers in the area to lay down their arms. ${ }^{35}$

On 13 July 1902, Bezuidenhout was part of a group of burghers who surrendered at Aliwal North. ${ }^{36}$ The laying down of arms or surrender by his unit took place at the town square and was overseen by Colonel Ternan. A detailed 
description of the laying down of arms was included in an account that appeared in the Northern Post and Boarder News of the same date. ${ }^{37}$

The two commandos were drawn up into two divisions, the rebels taking their position on the one side and the Free Staters on the other side. Some of the men possessed a couple of horses and the horses were not saddled. The burghers were on the whole well clothed and equipped with all the paraphernalia necessary ...They by no means look overjoyed. Their commandants and officers on the other hand looked fit and able men and showed no signs of humility and defeat. $^{38}$

Bezuidenhout returned to his farm Eldorado in the Rouxville district after the War, but still harboured feelings of deep bitterness regarding the incident that took place at Gatberg. He was specifically embittered about the role of the black auxiliaries and the undignified way in which his wounded father and the fallen burghers were treated.

On 27 October, Bezuidenhout submitted a complaint to the Attorney General, TL Graham of the Cape Colony, about the mutilation of the burghers after the battle and the manner in which the wounded had been "murdered". He attached to the letter a sworn affidavit by seven farmers who buried the fallen burghers on 21 November. The farmers who made depositions were J van Jaarsveld, W Muller, J Muller, F Botha, A van Jaarsveld, J Botha and J Herzelman. The farmers stated that they were sheep farmers and agriculturists in the district of Maclear. With reference to the clash at Gatberg and the demeanour of the black auxiliaries under the command of Captain Elliot, they declared as follows: "We found the black soldiers brutal. They all have rifles, assegais and knob kerries." 39

In the affidavit, the farmers stated that the bodies of the burghers were mutilated during and after the battle, and they included descriptions of the injuries inflicted: "The first was cut open and there was a hole through his head. His face was cut to pieces with an assegai and he was quite unrecognisable". ${ }^{40}$ The report of the second burgher was equally gruesome and was described as: "The second one was cut open. The intestines were almost quite out. His head was in pieces so that his brains were out ... his head was also shattered with kerries." was also reported to have been brutally murdered while the third burgher was also described as "cut open": "According to his bullet hole he was (only) wounded. His lower lip and the skin from his forehead were cut off. He was cut open and stabbed in the back so that we could see his intestines." 42 In his statement, Bezuidenhout 
declared: "I wish to bring to your notice a public murder committed by Natives or Kaffir (sic) troops and I hope that further steps will be taken by you, as our Colonial people are also often accused.",43

Bezuidenhout specifically refers to "murder" and not "killed in battle". (The small memorial that commemorated the battle in memory of the fallen burghers carried the following inscription on the lower section: "Wreed vermoor deur gewapende kaffers (sic) ${ }^{*}$ naby Gatberg" "44 [Viciously murdered by armed kaffirs (sic) near Gatberg]).

In reaction to Bezuidenhout's complaint, two British officers who were also involved in the Gatberg clash submitted their reports on the incident to the Attorney General. The first report was by Lieutenant Taylor, who outlined his recollection of the incident in an undated deposition. The second report was submitted on 26 November 1902 by Major Raw, who was based at Eland's Kloof, Kokstad. He subsequently submitted a report under the heading "Alleged murder by British Kaffir (sic) Troops".

Many of the allegations that were made by Bezuidenhout were refuted in the two subsequent reports, in which it was indicated that the burghers' wounds were not the result of knobkerries, but exit wounds caused by the high-calibre Snider rifle. ${ }^{45}$ The alleged mutilation of the bodies of the dead by disembowelling them as alleged by Bezuidenhout was according to Major Raw the result of a local custom 'to allow the spirit to leave the body': “... (all) the bodies had a small cut below the naval about two inches long, the cut was only through the skin and the lining of the stomach and intestines were not protruding". ${ }^{46}$ According to this statement, the facial injuries of the one burgher were a result of the fact that he had laid face-down in a stream and the disfiguration had been caused by crabs. ${ }^{47}$

In counter-accusations that were subsequently made, many of the headmen in the area protested that "they were ordered to give a quarter, but that they receive none from the enemy (Boers)". A few such incidents were listed by Lieutenant Taylor in his report. They also pointed out that two Boer prisoners were taken by the black troops at Gatberg and that they were treated fairly. ${ }^{48}$

\footnotetext{
* The term 'kaffir' (sic) is used with full knowledge that it is derogatory and offensive, but for purposes of historical accuracy, the word is reflected as it appears on the monument and in the primary sources.
} 
After the War, the entire controversy petered out, and the reports remained in the filing cabinet of the Attorney General for many years. No indication could be found in any source that the matter was taken any further or that any steps were taken to take the matter any further.

\section{Conclusion}

The general feelings of bitterness that were harboured about the deployment of black auxiliaries against the Boer Republics were reflected very clearly in many sources. The purpose of this article was not to explore the matter any further than has already been done by other authors on the subject, but rather to reflect on the experiences of a single participant in the South African War - Commandant Bezuidenhout - in order to provide insight into the feelings of bitterness that were prevalent amongst many Boer leaders and their followers. The incident at Gatberg on 20 November 1901 resulted in Commandant Bezuidenhout harbouring strong resentment, which dictated his political and public life until his death in $1941 .{ }^{49}$

In the final analysis it was evident that war and adversity do not bring out the best qualities in men. It is clear that both sides overstepped the boundaries, and that the truth is hidden somewhere between the accusations and counter-accusations of the two sides that were involved. This is very well articulated by Lieutenant Taylor, who mentioned in his report: "If as suggested, enquiry should be made into the charges of murder by Natives, the enquiry should extend also to the burghers." He then concluded: "In my humble opinion these regrettable incidents on both sides had best be consigned as early as possible to oblivion - let the dead bury their dead." $" 50$

After the War, a memorial was erected to commemorate the bravery of the burghers during the clash. For political reasons, the memorial was moved in 1994 from its initial position to a remote corner of the local cemetery. It displays the following inscription in Afrikaans: "PHS Bezuidenhout 57 jr. op dieselfde dag aldaar onder die wit vlag gesneuwel." ${ }^{, 51}$ (PHS Bezuidenhout, 57 years of age, who died under the white flag on the same day.)

\section{Endnotes}

${ }^{1}$ Warwick, P. Black people and the South African War. Johannesburg: Ravan Press, 1983, 22.

${ }^{2}$ Nasson, B. Abraham Esau's war: A black South African war in the Cape 18991990. Cambridge: Cambridge University Press, 1999, 13. 
${ }^{3}$ Warwick op. cit., p. 122; Nasson op. cit., p. 13.

${ }^{4}$ Nosipho, N. "Black involvement in the Anglo-Boer War 1899-1902". Military History Journal 11/3-4. 1999. 1.

${ }^{5}$ Warwick op. cit., p. 34.

${ }^{6}$ Amery, LS and Low, S (eds). The Times History of the War in South Africa 18991902, Volumes I-VII, London: Marston and Company Ltd, London, 19021909.

${ }^{7}$ Ibid., p. 18.

${ }^{8}$ Ibid., p. 154.

${ }^{9}$ McDonald, RDM. 'n Terugblik op my oorlogsjare. Johannesburg: Voortrekkerpers, 1949, 49.

${ }^{10}$ Ibid., p. 49.

${ }^{11}$ Spies, SB. Methods of barbarism. Johannesburg: Jonathan Ball, 2007, 307.

${ }^{12}$ Western Cape Archives and Record Service. CA ND. Report on letter by Commandant Bezuidenhout by Lieutenant Taylor, 27 October 1902, subject: Alleged murder by Natives of British Kaffir Troops. (Hereafter WCRC CA ND).

${ }^{13}$ Ibid.

${ }^{14}$ Oosthuizen, AV. Rebelle van die Stormberge. Pretoria: Perskor, 1992, 12.

${ }^{15}$ WCRC CA ND. Report on letter by Commandant Bezuidenhout by Lieutenant Taylor, 27 October 1908.

${ }^{16}$ Warwick op. cit., p. 116.

${ }^{17}$ Ibid., p. 116.

${ }^{18}$ Ibid., p. 23.

${ }^{19}$ WCRC CA ND. Report on letter by Commandant Bezuidenhout by Lieutenant Taylor, 27 October 1908.

${ }^{20}$ Northern Post and Border News. 13 June 1902.

${ }^{21}$ WCRC CA ND. Report on letter by Commandant Bezuidenhout by Lieutenant Taylor, 27 October 1908.

${ }^{22}$ Northern Post and Border News op. cit.

${ }^{23}$ WCRC CA ND. Letter from Commandant J Bezuidenhout to TL Graham, Attorney-General of the Cape, 27 October 1902.

${ }^{24}$ Northern Post and Border News op. cit.; WCRC CA ND. Report on letter by Commandant Bezuidenhout by Lieutenant Taylor, 27 October 1902.

${ }^{25}$ WCRC CA ND. Report on letter by Commandant Bezuidenhout by Major WF Raw.

${ }^{26}$ The Times Digital Archive, 1785-1985, November 23, 1901, Issue 36620.

${ }^{27}$ Ibid. 
${ }^{28}$ South-Africa-Immigrants-British-L-Archives.

〈http://arhiver.rootsweb/th/read/SOUTH-AFRICAN-IMMIGRANTS >

Accessed on 3 August 2012.

${ }^{29}$ Northern Post and Border News op. cit.

${ }^{30}$ Interview: CEB Grobler, Theunissen, 19 March 2005 (daughter of Commandant Bezuidenhout).

${ }^{31}$ WCRC CA ND. Report on letter by Commandant Bezuidenhout by Lieutenant Taylor, 27 October 1908.

${ }^{32}$ Interview: CEB Grobler, Theunissen, 19 March 2005.

${ }^{33}$ Oosthuizen op cit., p. 45.

${ }^{34}$ Official Report from Capt Clockwell to Commandant Bezuidenhout, dated 3 June 1902 (private collection).

${ }^{35}$ Letter from Genl. Fouché to Commandant Bezuidenhout, dated 8 June 1902 (private collection).

${ }^{36}$ Northern Post and Border News op. cit.

${ }^{37}$ Ibid.

${ }^{38}$ Ibid.

${ }^{39}$ WCRC CA ND. Sworn affidavit attached to the letter J Bezuidenhout to TL Graham, 27 October 1902.

${ }^{40}$ Ibid.

${ }^{41}$ Ibid.

${ }^{42}$ Ibid.

${ }^{43}$ WCRC CA ND. Sworn affidavit attached to the letter J Bezuidenhout to TL Graham, 27 October 1902.

${ }^{44}$ In loco inspection.

${ }^{45}$ WCRC CA ND. Report on letter by Commandant Bezuidenhout by Lieutenant Taylor, 27 October 1908.

${ }^{46}$ Ibid.

${ }^{47}$ Ibid.

${ }^{48}$ Ibid.

${ }^{49}$ Interview: CEB Grobler, Theunissen, 19 March 2005.

${ }^{50}$ WCRC CA ND. Report on letter by Commandant Bezuidenhout by Lieutenant Taylor, 27 October 1908.

${ }^{51}$ In loco inspection: The monument is located in the southern side of the cemetery at Ugie. 